\title{
XXXIV. On a piezo-electric pile
}

\section{Lord Kelvin}

To cite this article: Lord Kelvin (1893) XXXIV. On a piezo-electric pile, Philosophical Magazine Series 5, 36:221, 342-343, DOI: 10.1080/14786449308620485

To link to this article: http://dx.doi.org/10.1080/14786449308620485

$$
\text { 曲 Published online: } 08 \text { May } 2009 .
$$

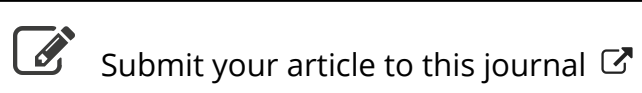

\footnotetext{
Џ Article views: 4
}

Q View related articles ¿ 
dimension parallèle de l'axe optique n'a pas d'influence sur la quantité d'électricité dégagée *.

La lame de quartz est placée dans une enceinte métallique desséchée. Cette cage métallique, toutes les pièces métalliques de l'instrument et les montures de la lame de quartz sont mises en communication permanente avec la terre.

Le modèle no. 2 comporte encore un commutateur et un levier qui sert à soulever les plateaux et les poids. Nous reviendrons plus loin sur le rôle de ces organes.

\section{On a Piezo-electric Pile. By Lord KeLvin †.}

THE application of pressure to a voltaic pile, dry or wet, 1 has been suggested as an illustration of the piezo-electric properties of crystals, but no very satisfactory results have hitherto been obtained, whether by experiment or by theoretical considerations, so far as I know. Whatever effects of pressure have been observed have depended upon complex actions on the moist, or semi-moist, substances between the metals, and electrolytic or semi-electrolytic and semi-metallic conductances of these substances. Clearing away everything but air from between the opposed metallic surfaces of different quality, I have made the piezo-electric pile which accompanies this communication. It consists of twenty-four double plates, each 8 centimetres square, of zinc and copper soldered together, zinc on one side and copper on the other. Half a square centimetre is cut from each corner of each zinc plate, so that the copper square is left uncovered by the zinc at each of its four corners. Thus each plate presents on one side an uninterrupted copper surface, and on the other side a zinc surface, except the four uncovered half square centimetres of copper. A pile of these plates is made, resting one over the other on four small pieces of india-rubber at the four copper corners. The air-space between the opposed zinc and copper surfaces may be of any thickness from half a millimetre to 3 or 4 millimetres. Care must be taken that there are no minute shreds of fibre or dust bridging the air-space. In this respect so small an air-space as half a millimetre gives trouble, but with 3 or 4 millimetres no trouble is found.

The lowest and uppermost plates are connected by fine

* Double breadth, with doubled stretching force, would give double quantity.

t Communicated by the Author, having been read before Section A of the British Association at its recent meeting in Nottingham. 
wires to the two pairs of quadrants of my quadrant electrometer, and it is generally convenient to allow the lowest to lie uninsulated on an ordinary table and to connect it metallically with the outer case of the electrometer.

To make an experiment, (1) connect the two fine wires metallically, and let the electrometer-needle settle to its metallic zero.

(2) Break the connexion between the two fine wires, and let a weight of a few hektogrammes or kilogrammes fall from a height of a few millimetres above the upper plate and rest on this plate. A startlingly great deflexion of the electrometerneedle is produced. The insulation of the india-rubber supports and of the quadrants in the electrometer ought to be so good as to allow the needle to come to rest, and the steady deflexion to be observed, before there is any considerable loss.

If, for example, the plates are placed with their zine faces up, the application of the weight causes positive electricity to come from the lower face of the uppermost plate and deposit itself over the upper surface of plate and weight, and on the electrode and pair of quadrants of the electrometer conneeted with it.

XXXV. On the Oscillations of Lightning Discharges and of the Aurora Borealis. By JOHN Trowbridge*.

\section{[Plate III.]}

T $\mathbf{T}$ is well known that when air is subjected to a sudden strain at the moment of an electrical discharge, it acts like glass or a similar elastic solid and is cracked in zigzag fissures; indeed the resemblance between the ramifications of lightning and the seams produced in plates of glass by pressure has been commented upon by various observers. Photographs of powerful electric sparks lead one to conclude that a discharge of lightning makes way for its oscillations by first breaking down the resistance of the air by means of a disruptive pilot spark : through the hole thus made in the air the subsequent surgings or oscillations take place.

In examining the early photographs, taken by Feddersen, of electric sparks, one perceives indications that the electric oscillations tend to follow, for at least some hundred-thousandths of a second, the path made by the pilot spark; and there are observers who believe that by rapidly moving a camera they

* Communicated by the Author. 